\title{
Superconducting nanowire photon-number-resolving detector at
} telecommunication wavelengths

ALEKSANDER DIVOCHIY, FRANCESCO MARSILI, DAVID BITAULD, ALESSANDRO GAGGERO, ROBERTO LEONI, FRANCESCO MATTIOLI, ALEXANDER KORNEEV, VITALIY SELEZNEV, NATALIYA KAUROVA, OLGA MINAEVA, GREGORY GOL'TSMAN, KONSTANTINOS G. LAGOUDAKIS, MOUSHAB BENKHAOUL, FRANCIS LÉVY AND ANDREA FIORE

Nature Photonics 2, 302-306 (2008)

In the above article, the authors wish to correct the misspelling of the 13th author's name, which should have read:

Moushab Benkahoul 